\title{
Protein quality of winter wheat depending on the dressing with sulfur-containing nitrogen fertilizers applied in early spring
}

\author{
F.A. Mudarisov ${ }^{1}$, V.I. Kostin ${ }^{1}$, Yu.M. Isaev ${ }^{1}$, A.I. Semashkina ${ }^{1}$, N.M. Semashkin ${ }^{1, *}$, and \\ M.K. Sadygova ${ }^{2}$ \\ ${ }^{1}$ Ulyanovsk State Agrarian University, Ulyanovsk, Russia \\ ${ }^{2}$ N.I. Vavilov Saratov State Agrarian University, Saratov, Russia
}

\begin{abstract}
The paper contains the study results of the effect of sulfurcontaining nitrogen fertilizers on the quality of protein in winter wheat grain grown in the Ulyanovsk region on soils with a lack of sulfur. The experimental crop is soft winter wheat, the variety "Saratovskaya - 17". As a result, it was found that the biological value of protein compared to the control option increased by $11.5 \%$ in the option with the use of $5 \%$ of sulfur.
\end{abstract}

\section{Introduction}

Sulfur as a macroelement, is vital for various metabolic processes in plants, it participates in the biological cycle of substances, is a component of amino acids (AA): cysteine, cystine and methionine, and is also part of the most important biological compounds - coenzyme A and vitamins (lipoic acid, biotin, thiamine). The macroelement is also involved in redox processes [1].

Insufficient supply of plants with sulfur inhibits the synthesis of sulfur-containing amino acids and proteins, reduces photosynthetic activity and plant growth rate [2]. Proceeding from this, it becomes necessary to use sulfur-containing fertilizers, especially on those soils in which the sulfur content is low.

The results of numerous studies [3,4,5,6,7] indicate the effectiveness of the use of sulfur when growing crops, in particular, it was found that under the influence of sulfur-containing fertilizers there is an increase in the yield of spring wheat and rape. Sulfur-containing fertilizers are used in the optimization of mineral nutrition in gray forest, sod-podzolic soils, typical and ordinary chernozems.

\section{Materials and methods of research}

One of the main problems of grain quality is linked with an increase in the biological value of protein, due to the amino acid composition. According to the Bryansk State Agricultural Academy, with an increase in the doses of mineral fertilizers, the total amino acid content in the grain of the variety "Galina" increased in comparison with the accepted biological

\footnotetext{
* Corresponding author: exis@yandex.ru
} 
technology. In options with intensive technology (NPK) $)_{120}$, the total amino acid content and the content of essential amino acids in the grain were the highest in both options [2].

The Belarusian Institute of Soil Science and Agrochemistry found that the use of nitrogen, phosphorus and potassium fertilizers increases the amount of essential amino acids in the grain of winter triticale. The maximum amount of 7 essential amino acids - 27.71-27.75 g / $\mathrm{kg}$, including three critical amino acids - 7.24-7.27 g / kg, in grain is typical for fertilization systems $\mathrm{N}_{90+30+30} \mathrm{P}_{70} \mathrm{~K}_{120}$ and $\mathrm{N}_{90+30+30} \mathrm{P}_{40} \mathrm{~K}_{80}$. The use of nitrogen fertilizers reduces the amount of essential and critical amino acids in the protein of winter triticale. The biological value (BV) of winter wheat protein, estimated by the "chemical number" of critical amino acids AA - 56.7\% and by the "amino acid score" AA - 75.0\%, the maximum amount when using $\mathrm{P}_{20} \mathrm{~K}_{40}$. The biological value of winter triticale protein, estimated by the "chemical number" of indispensable amino acids AA - 78.6\% and by the "amino acid score" AA - 101.4\%, the maximum amount when using $\mathrm{P}_{40} \mathrm{~K}_{80}$ [8].

However, the most significant effect on the increase in the quantity and biological value of protein is exerted by mineral fertilizers and the condition of soil fertility. Yields of winter wheat and grain quality largely depend on the availability of plants with elements of mineral nutrition and scientifically substantiated fertilization systems [8].

Due to the low sulfur content in the soil where the experiments were conducted, the aim of the study was to investigate the effect of ammonium nitrate $+5 \%$ and $10 \%$ S during early spring dressing on the yield and quality of winter wheat.

Field experiments were conducted from 2016 to 2018. on the experimental field of P.A. Stolypin Ulyanovsk State Agrarian University. The experimental crop is soft winter wheat, the variety Saratovskaya - 17.

The soil of the experimental plot is leached chernozem, of medium thickness, with low humus content, medium loamy. The humus content is $4.3 \%$. The availability of mobile phosphorus is elevated, and exchangeable potassium is high. The content of P2O5 is 115, $\mathrm{K} 2 \mathrm{O}$ is $139 \mathrm{mg} / \mathrm{kg}$ of soil. The reaction of the medium in the arable layer is weakly acidic $\mathrm{pH}$ - 6.1. The degree of saturation with bases of $26.5 \mathrm{mg}-\mathrm{eq} / 100 \mathrm{~g}$ of soil. The sulfur content is very low, in the range of $0.3-1.3 \mathrm{mg} / \mathrm{kg}$ of soil.

Farming practice is generally accepted for this crop with the use of modern machinery. The registered plot area is $15 \mathrm{~m}^{2}$. The total area is $210 \mathrm{~m}^{2}$. The replication of the experiment is fourfold. The layout of the plots is randomized.

Ammonium nitrate, including sulfur-containing, was used to carry out early spring dressing, at the rate of $\mathrm{N} 100, \mathrm{~S} 5 \%$ and S $10 \% \mathrm{~kg}$ / ha in the active substance.

Field experiment scheme:

1) NH4NO3 (control) - early spring dressing with ammonium nitrate);

2) NH4NO3 + S (5\%) - early spring dressing with ammonium nitrate and ammonium sulfate.

3) NH4NO3 + S (10\%) - early spring dressing with ammonium nitrate and ammonium sulfate.

The variety Saratovskaya - 17 was included in the State Register of Selection Achievements Allowed for Use in 2009 in the Middle Volga and Central Black Earth Regions of the Russian Federation.

In the experiments, the following observations, counts and analyzes were carried out:

- yield was determined by continuous threshing with the Terrion-Sampo SR2010 selection combine harvester;

- registration of the actual harvest was carried out in view of the entire plot area with conversion to $100 \%$ purity and $14 \%$ humidity (GOST $27548-97$ );

-protein content was determined according to protein nitrogen (determination with the use of Barnstein method), followed by multiplication by a coefficient of 5.7 (GOST 1084691); 
- the content of indispensable amino acids was determined by the method of capillary electrophoresis on a system of capillary electrophoresis "Kapel 105M" in accordance with the adapted method M-04-38-2009 (FR.1.31.2010.07015).

The results of the study were mathematically processed with the help of the analysis of variance [9].

The biological value (BV) of proteins during thermal, mechanical, ultrasonic or other types of processing, as well as during transportation and storage of grain, may decrease, especially due to the interaction of essential amino acids, often lysine, with other components. In this case, compounds inaccessible for digestion in the human body are formed. At the same time, the BV and AAS of proteins can be increased by formulating product mixtures or by adding the missing and labile indispensable amino acids. For example, a combination of proteins of wheat and soybeans, in a certain ratio, provides a complete set of amino acids.

The calculation of the biological value of protein was carried out according to the formula [10]:

$$
B V=100-C A A S D .
$$

The coefficient of amino acid score differences (CAASD, \%) shows an excessive number of indispensable amino acids used in biochemical processes, and it is calculated as the average excess value of $A A S$ of an indispensable amino acid relative to the smallest score of a given acid:

$$
\begin{gathered}
C A A S D=\sum \triangle D A A S / n ; \\
\triangle D A A S=\triangle A A S_{i}+A A S_{\min },
\end{gathered}
$$

where $\triangle D A A S$ - difference of the amino acid score, \%; $\mathrm{n}$ - number of indispensable amino acids (IAA); $\triangle A A S_{\mathrm{i}}$ - an excess of the score of an i-amino acid, \% $\left(\triangle A A S_{\mathrm{i}}=A A S_{\mathrm{i}}-100\right.$, $A A S_{\mathrm{i}}$ - the amino acid score for an i- indispensable acid); $A A S_{\min }$ - the score of a limiting acid, \%.

The coefficient of utilization of i-IAA $\left(K_{\mathrm{i}}\right)$ - the characteristic that reflects the balance of an indispensable amino acid in relation to reference protein. It is calculated according to the formula:

$$
K_{i}=A A S_{\min } / A A S_{\mathrm{i}}
$$

The rationality coefficient of the amino acid composition $\left(R_{c}\right)$ reflects the balance of an indispensable amino acid relative to reference protein and calculated according to the formula:

$$
R_{c}=\sum_{i=1}^{k} A_{i} K_{i} / \sum_{i=1}^{k} A_{i}
$$

where $\mathrm{K}_{\mathrm{i}}$ - the coefficient of utilization of an i-IAA; $\mathrm{A}_{\mathrm{i}}$ - the mass share of an i-amino acid in one gram of reference protein, $\mathrm{mg} / \mathrm{g}$.

The amino acids tryptophan, lysine, methionine are especially valuable, the ratio of which in the nutritive ration should be 1: 3: 3 . The calculation of amino acid scores is based on a comparison of the amino acid composition of protein of food products with the amino acid composition of reference("ideal") protein [10]. Amino acid, the speed of which is of the least importance, is called limiting. The limiting amino acids are often lysine, threonine, tryptophan and sulfur-containing amino acids (methionine, cysteine). Consideration of the weather conditions of throughout a year is of great importance for agricultural producers. The growth and development of cultivated plants, their yield has a large dependence on the 
amount of precipitation, distribution during the vegetation period of plants, air temperature, time and rate of warming the soil, the sum of positive temperatures for the growing season, etc.

Meteorological conditions satisfy the requirements of the experimental crop, although the lack of moisture, droughts and dry winds have a negative effect on the formation of winter wheat crop. For all three years of research, the phase of full ripeness began approximately in mid-July.

2016/2017. The autumn of 2016 was marked by a rather large amount of precipitation, especially in September (56mm), which had a favorable influence on the even emergence of seedlings of winter wheat. In winter, steady low daily average temperatures (from -5 to -11 ${ }^{\circ} \mathrm{C}$ ) were observed. Snow cover formed was relatively shallow which led to partial plant freezing and damage. In the spring, there was little rainfall. In the spring-summer period precipitation was more than normal. A particularly large amount of precipitation was observed in July (163 mm), which led to lodging of plants and the postponement of harvesting.

The critical amount of precipitation (91 mm) that fell on July 5, 2017 and gusty wind led to widespread lodging of winter wheat, which complicated the harvesting of the experimental crop and postponed the start of harvesting by two weeks. Losses of grain during threshing also increased, part of the grain did not meet the basic standards for humidity and other indicators of harvesting conditions.

2017/2018. The autumn of 2017 differed from the previous year in low rainfall. In September, only $34 \mathrm{~mm}$ fell. In winter, steady low temperatures were observed at $2-5^{\circ}$ below 2017 (exception January 2018). Compared to January and February, in March, more precipitation fell per month at an air temperature of $8^{\circ}$ below the previous year. In 2018, compared with the previous year, the spring vegetation of the experimental crop due to low positive temperatures began 7-10 days later than usual. The air temperature at night until the end of the first decade of June did not rise above $3-5^{\circ} \mathrm{C}$. On the ground, frequent frosts were observed in some areas. The date of occurrence of phenophases (shooting-flowering-ear formation) was delayed by 2 weeks. The amount of precipitation from May to July 2018 varied from 16 to $30 \mathrm{~mm}$ per month. A sharp increase in daily air temperature to $28-33^{\circ} \mathrm{C}$ with a low rainfall in July and August accelerated the period of grain filling. Before August 10, after the onset of the phase of complete ripeness, the crop was harvested. The moisture content of the grain during harvesting did not exceed $14 \%$.

\section{Results of the research}

Both weather conditions and mineral fertilizers had an effect on the yield of winter wheat Saratovskaya-17 during the years of research 2017-2018. On average, over two years, the maximum grain yield is $4.58 \mathrm{t}$ / ha (Table 1 ).

Table 1. Yield of winter wheat, t/ha (2017-2018)

\begin{tabular}{|c|c|c|c|c|c|c|}
\hline \multirow[t]{2}{*}{ № } & \multirow[t]{2}{*}{ Options } & \multicolumn{3}{|c|}{ Years of research } & \multicolumn{2}{|c|}{ Increase } \\
\hline & & 2017 & 2018 & Mean & t/ha & $\%$ \\
\hline 1. & $\begin{array}{l}\text { NH4NO3 } \\
\text { (control) }\end{array}$ & 4,19 & 4,45 & 4,32 & - & 100 \\
\hline 2. & NH4NO3 +S5 \% & 4,38 & 4,65 & 4,51 & 0,19 & 104,4 \\
\hline 3. & $\begin{array}{ll}\text { NH4NO3 }+ \text { S10 } \\
\%\end{array}$ & 4,63 & 4,53 & 4,58 & 0,26 & 106 \\
\hline & $\mathrm{HCP}_{05}$ & 0,43 & 0,12 & & & \\
\hline
\end{tabular}


The data in table 1 and figure 1 shows that sulfur-containing fertilizers had a positive effect on the yield of the studied variety of winter wheat. Based on the data using the methods of correlation and regression analyzes [10], a regression equation was derived to calculate the change in the yield of $y$ ( $\mathrm{t} / \mathrm{ha}$ ) of winter wheat depending on the percentage of ammonium sulfate $x(\%)$ in early spring dressing in the form of the formula [11]:

$$
y=4,32+0,051 x-0,00251 x^{2}
$$

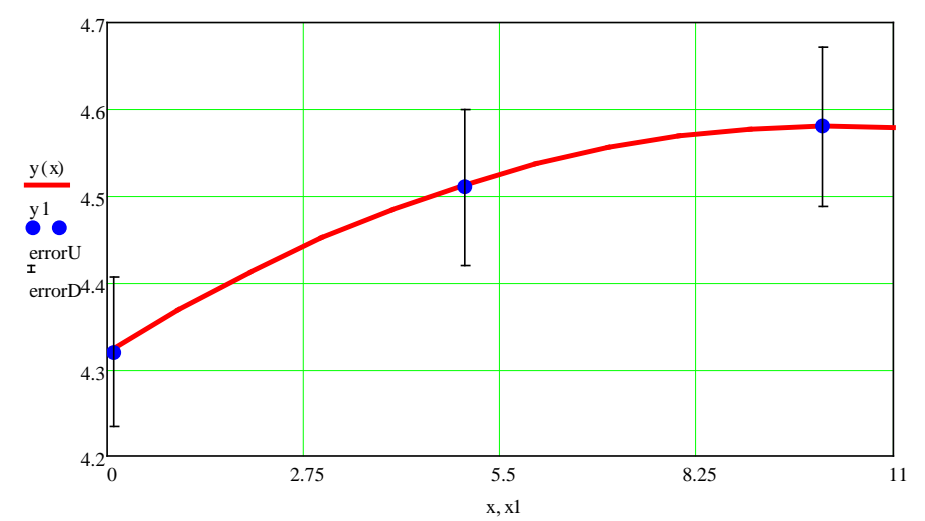

Fig. 1. Change in yielding capacity $y$ (t / ha) of winter wheat, depending on the percentage of the ammonium sulfate content $x(\%)$ in early spring dressing.

According to the results of one factor analysis of variance in 2017, in the option NH4NO3 + S 5\%, in 2018 and in the option NH4NO3 + S 5\%, there was a yield increase, within the extent of the experimental error. On average, over two years of research in the option $\mathrm{NH} 4 \mathrm{NO} 3+\mathrm{S} 10 \%$, the yield of winter wheat increased up to $0.26 \mathrm{t} /$ ha $(+6 \%$ compared with the control option).

The amino acid content according to the experimental options in the flour of the experimental crop and in protein studied is shown in table 2.

Table 2. Content of amino acids, $\mathrm{mg} / \mathrm{g}$

\begin{tabular}{|c|c|c|c|c|c|c|c|}
\hline \multirow[t]{3}{*}{ Amino acids } & \multicolumn{7}{|c|}{ Content of amino acids } \\
\hline & \multicolumn{3}{|c|}{ In flour, mg/g } & \multirow{3}{*}{$\begin{array}{l}\text { In } \\
\text { referen } \\
\text { ce } \\
\text { protein } \\
\text {, mg/g }\end{array}$} & \multirow{2}{*}{\multicolumn{3}{|c|}{$\begin{array}{c}\text { In protein studied, } \mathrm{mg} / \mathrm{g} \\
\text { Options }\end{array}$}} \\
\hline & \multicolumn{3}{|c|}{ Options } & & & & \\
\hline 1 & Control & $+\mathrm{S} 5 \%$ & $+\mathrm{S} 10 \%$ & & Control & $+\mathrm{S} 5 \%$ & $+\mathrm{S} 10 \%$ \\
\hline 1. Isoleucine & \multirow[t]{2}{*}{17,7} & \multirow[t]{2}{*}{18,5} & \multirow[t]{2}{*}{18,6} & \multirow[t]{2}{*}{110} & \multirow[t]{2}{*}{156,8} & \multirow[t]{2}{*}{161,5} & \multirow[t]{2}{*}{193,2} \\
\hline 2. Leucine & & & & & & & \\
\hline 3. Lysine & 1,6 & 1,7 & 1,6 & 55 & 14,2 & 14,8 & 16,6 \\
\hline 4. Methionine & \multirow[t]{2}{*}{4} & \multirow[t]{2}{*}{4,1} & \multirow[t]{2}{*}{3,7} & \multirow[t]{2}{*}{35} & \multirow[t]{2}{*}{35,4} & \multirow[t]{2}{*}{36,1} & \multirow[t]{2}{*}{38,4} \\
\hline 5. Cystine & & & & & & & \\
\hline $\begin{array}{l}6 . \\
\text { Phenylalanine }\end{array}$ & 15,2 & 8,1 & 10,1 & \multirow[t]{2}{*}{60} & \multirow[t]{2}{*}{162,1} & \multirow[t]{2}{*}{98,6} & \multirow[t]{2}{*}{139,1} \\
\hline 7. Tyrosine & 3,1 & 3,2 & 3,3 & & & & \\
\hline 8. Threonine & 3,2 & 3,3 & 3,8 & 40 & 28,3 & 28,8 & 39,5 \\
\hline 9. Tryptophan & 0,9 & 1 & 0,9 & 10 & 8 & 8,7 & 9,3 \\
\hline 10. Valine & 4,6 & 4,8 & 4,7 & 50 & 40,7 & 41,9 & 48,8 \\
\hline Total & 50,3 & 44,7 & 46,7 & 360 & 445,5 & 390,4 & 484,9 \\
\hline
\end{tabular}


From the data of table 2, it is clear that after the use of sulfur-containing nitrogen fertilizers in the flour of the experimental crops, a difference is observed in the content of indispensable amino acids (IAA). In option 2, the content of isoleucine with leucine, lysine, tyrosine, threonine, tryptophan, valine increases by $0.1-0.8 \mathrm{mg} / \mathrm{g}$ of protein. With an increase in the dose of sulfur, the content of isoleucine with leucine, tyrosine, threonine and valine doubles by 0.1-0.9 $\mathrm{mg} / \mathrm{g}$ of protein.

As for the total content of indispensable amino acids in terms of protein, their maximum accumulation of $484.9 \mathrm{mg}$ / g of protein is observed in the third option. The limiting content of lysine, threonine, tryptophan and valine in protein is present in all three options.

However, the amino acid score (AAS) of protein in option 3 is low only in lysine content (Figure 2).

During spring root dressing with sulfur-containing ammonium nitrate, the AAS increases in experimental options in isoleucine with leucine by $4.2-33 \mathrm{mg} / \mathrm{g}$, in lysine by $1.2-4.4 \mathrm{mg}$ / g, in methionine with cystine by $2.1-8,6 \%$, in threonine by $1.2-28 \%$, in tryptophan by $7.2-$ $13 \%$, in valine by $6.4-16.2 \%$. When using sulfur at a concentration of $10 \%$ in ammonium nitrate leads to an increase in the AAS. In the control option, the AAS in lysine is only $25.8 \%$; in the option with the use of sulfur, $5 \%$ of the AAS increases by $1.2 \%$ and is $27 \%$. The application of sulfur-containing ammonia nitrate with a sulfur concentration of $10 \%$ leads to an increase in the AAS compared with the control option by $4.4 \%$, where the AAS is $30.2 \%$.

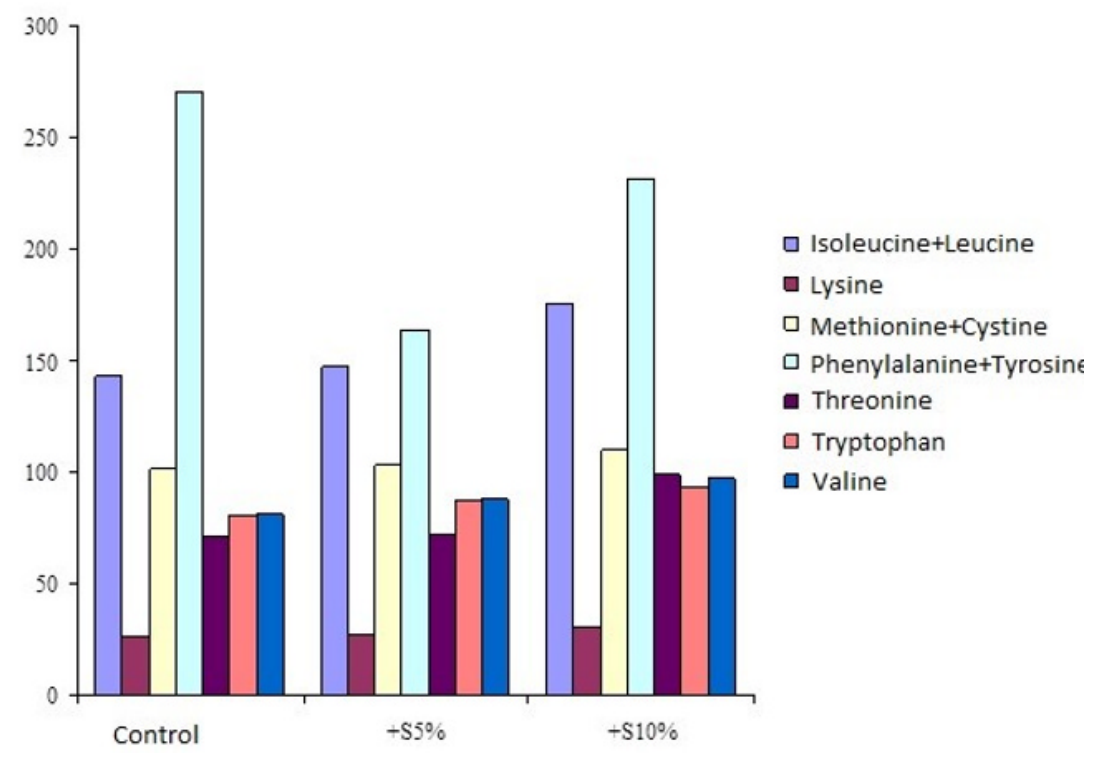

Fig. 2. Amino acid score (\%) according to the experimental options

The second and third limiting amino acids in the control option and in the first option with sulfur are threonine and tryptophan, in the second option with sulfur are tryptophan and valine.

According to table 3, an excess amount of an IAA not used for biochemical processes of the organism is observed in all cases, but the maximum CAASD is observed in the option with sulfur $10 \%$, where it was $78.2 \%$, which is by $15.8 \%$ higher than in the first experimental option with sulfur and by $4.3 \%$ higher than in the control option. 
Table 3. Protein quality indicators

\begin{tabular}{|c|c|c|c|}
\hline \multirow[t]{2}{*}{ Amino acids } & \multicolumn{3}{|c|}{$\mathrm{Ki}$} \\
\hline & \multicolumn{3}{|c|}{ Options } \\
\hline 1 & Control & $+\mathrm{S} 5 \%$ & $+\mathrm{S} 10 \%$ \\
\hline 1. Isoleucine & \multirow[t]{2}{*}{0,18} & \multirow[t]{2}{*}{0,18} & \multirow[t]{2}{*}{0,17} \\
\hline 2. Leucine & & & \\
\hline 3. Lysine & 1 & 1 & 1 \\
\hline 4. Methionine & \multirow[t]{2}{*}{0,26} & \multirow[t]{2}{*}{0,26} & \multirow[t]{2}{*}{0,28} \\
\hline 5. Cystine & & & \\
\hline 6. Phenylalanine & \multirow[t]{2}{*}{0,1} & \multirow[t]{2}{*}{0,16} & \multirow[t]{2}{*}{0,13} \\
\hline 7. Tyrosine & & & \\
\hline 8. Threonine & 0,36 & 0,38 & 0,31 \\
\hline 9. Tryptophan & 0,32 & 0,31 & 0,31 \\
\hline 10. Valine & 0,32 & 0,31 & 0,31 \\
\hline CAASD, \% & 73,9 & 62,4 & 78,2 \\
\hline $\mathrm{BV}, \%$ & 26,1 & 37,6 & 21,8 \\
\hline Rc, \% & 0,28 & 0,33 & 0,25 \\
\hline
\end{tabular}

The biological value of protein compared with the control option increased in the option with the use of $5 \%$ of sulfur by $11.5 \%$. This is due to the fact that the AAS of indispensable amino acids in the aforementioned option is closer to the recommended standards of the UN Food Committee and the World Health Organization (FAO / WHO) in comparison with other options.

\section{Conclusions}

Comparing the utilization coefficients of the amino acid composition, it should be noted that phenylalanine + tyrosine is the lesser option for utilization of indispensable amino acids in the wheat flour protein in all cases, the lowest indicator is noted in the control option.

IAAs are most balanced in relation to the physiologically necessary norm (standard) in the protein complex of wheat flour in the option with ammonium nitrate with $5 \%$ of sulfur.

Thus, according to the results of the studies, we can draw the following conclusion. The most balanced protein content of indispensable amino acids with a higher biological value is the protein complex of flour in option 2 with the use of sulfur-containing ammonium nitrate with $5 \%$ of sulfur. 


\section{References}

1. Sabinin, D.A. The physiological basis of mineral nutrition, D.A. Sabinin // M.: Publishing House. USSR Academy of Sciences, 1965. - p. 512.

2. Melnikova, O.V. The effect of mineral fertilizers on the amino acid content in the grain of winter wheat / O.V. Melnikova, I.I. Fokin / Agronomical Bulletin, 2009. - No. 5. - p. 40.

3. Bystrova, M.S. (Patrina, M.S.), Tandelov, Yu.P. The effectiveness of the use of sulfurcontaining fertilizers on acidic soils of the Krasnoyarsk Territory // Youth of Siberia-to science of Russia: materials of interregional, scientific conference. - Krasnoyarsk: SIBUP; KRO NS “Inegration”, 2003.- Part 1.- pp. 84-87.

4. Kostin, V.I. The effect of sulfur-containing fertilizers in early spring dressing on the yield and quality of winter wheat / V.I. Kostin, F.A. A.I. Semashkina // Niva Povolzhya. - 2018 .-- No. 1 (46) .- pp. 29-35.

5. Patrina, M.S. The role of sulfur-containing fertilizers in optimizing the mineral nutrition of the gray forest and sod-podzolic soils of the Krasnoyarsk subtaiga // Bulletin of KrasSAU. - 2011.- Vol. 10.- pp. 40-45.

6. Tandelov, Yu.P. The effect of sulfur-containing fertilizers on the yield of spring wheat and rapeseed in Central Siberia / Yu.A. Tandelov, M.S. Bystrova (M.S. Patrina) // Bulletin of the KrasSAU. 2007. - Issue 3. - pp. 78-84.

7. Tandelov, Yu.P., Bystrova, M.S. (Patrina, M.S.). The effectiveness of sulfur-containing fertilizers on acid soils of the Krasnoyarsk Territory // Soils - National Treasure of Russia: Materials of the IV Congress of the Dokuchaev Society of Soil Scientists. - Novosibirsk: Nauka-Center, 2004. - Book 2.-pp.111-112.

8. Lapa, V.V. The influence of fertilization systems on the grain quality of winter triticale during cultivation on sod-podzolic sandy loamy soil / V.V. Lapa et al. // Soil Science and Agricultural Chemistry, 2012. - No. 1 (48). - pp. 45-54.

9. Dospekhov, B.A. The field experiment technique (with the basics of statistical processing of research results) / B.A. Dospekhov $/ / 6^{\text {th }}$ ed. Add. and revised. - M.: Agropromizdat, 2011 . p. 352.

10. Recommendations for determining the biological value of protein of agricultural crops / I.M. Bogdevich [et al.]; NAS of Belarus, Institute of Soil Science and Agricultural Chemistry; under the editorship of I.M. Bogdevich. - Minsk, 2005 . p. 14.

11. Isaev Yu. M, Kryuchin N.P, Semashkin N. M and Kryuchin A. N, Theoretical Studies of Movement of Loose Material in a Dosing Device, International Journal of Mechanical Engineering and Technology, 9(5), 2018, pp. 834-840 http://www.iaeme.com/IJMET/issues.asp?JType=IJMET\&VType=9\&IType=5 